\title{
Isolation and Preliminary Characterization of Temperature-Sensitive Mutants of Influenza Virus
}

\author{
A. SUGIURA, ${ }^{1}$ K. TOBITA, AND EDWIN D. KILBOURNE \\ Department of Microbiology, Mount Sinai School of Medicine, The City University of New York, \\ New York, New York 10029
}

Received for publication 17 April 1972

\begin{abstract}
Isolation of temperature-sensitive (ts) mutants was attempted from the WSN strain of influenza A virus which was grown and assayed in MDBK cells. After growth of wild-type virus in the presence of 5-fluorouracil, 15 ts mutants were selected for which the ratio of plaquing efficiency at $39.5 \mathrm{C}$ to that at $33 \mathrm{C}$ was $10^{-3}$ or less. In pairwise crosses of ts mutants, recombination and complementation were either very efficient or undetectable. It is suggested, therefore, that the viral genome consists of physically discrete units and recombination occurs as an exchange of these units. All 15 mutants have been assigned with certainty into five recombination groups. Three mutants are suspected to be double mutants. Any two complementing mutants always recombined with each other, and noncomplementing mutants did not recombine. In physiological tests, mutants showed diverse patterns of functional defects at the nonpermissive temperature. However, it was not always possible to correlate these physiological defects with the results of genetic characterization.
\end{abstract}

Genetic recombination occurs with very high efficiency with influenza $A$ viruses $(13,24,28$, 29). This led to the important hypothesis that the genome of influenza virus consists of several distinct subgenomic fragments and that genetic recombination occurs almost exclusively by an independent assortment of these fragments (12). Thus far, genetic studies have not provided definitive evidence for or against the hypothesis, although it has had considerable support from biophysical and biochemical studies of viral ribonucleic acid (RNA) and nucleocapsid (2, 4-7, 14, 17, 20-22). A promising approach for genetic analysis is the use of temperaturesensitive conditional lethal mutants (ts mutants) (9). Two independent studies along this line with the WSN strain of influenza virus have been reported $(19,25)$. Their results, however, were at variance in some important respects.

Genetic studies of influenza virus have been hampered by the occurrence of the von Magnus phenomenon, the production of incomplete virus during one-step growth after high multiplicity infection, the latter procedure being a prerequisite for quantitative analyses. The resulting reduced yield of infectious virus often obscures increase of progeny virus beyond the background virus titer. If most single-step ts mutants of ribovirus are likely to be associated with leakiness

\footnotetext{
1 Present address: The Institute of Public Health, Shirokanedai, Minato-ku, Tokyo 108, Japan.
}

and high reversion rate (3), demonstration of clear-cut evidence of complementation and determination of recombination frequency would be particularly difficult under the circumstances of the von Magnus phenomenon. It has been reported that the von Magnus phenomenon is partly host-dependent and that MDBK cells are relatively insensitive to the effect, producing a high yield of infectious virus even after the inoculation of a large dose of the WSN strain of influenza virus (1). Therefore, MDBK cells appeared to offer a uniquely suitable host cell system for the genetic study of WSN virus. The relative homogeneity of the cell population characteristic of a continuous cell line which can be cloned, if desired, offers an additional advantage. On the other hand, the reported low efficiency of plaquing of WSN on this cell line (1) made us hesitant initially to use it for virus assay. However, we have achieved a significant increase in plaquing efficiency by careful selection of plaque assay procedures. With the improved techniques, MDBK cells were found to be at least as susceptible to WSN virus as the allantoic cavity of the chicken embryo or clone 1-5C-4 cells (27). Using the system of WSN virus and a cloned line of MDBK cells, we have attempted to collect ts mutants of WSN virus. This communication describes mutagenization of virus, isolation of ts mutants, and their preliminary characterization. 


\section{MATERIALS AND METHODS}

Cells. A cloned line was derived from the MDBK line of bovine cells kindly given us by $\mathrm{P}$. W. Choppin. Cells were propagated in plastic bottles as previously described (1). Cultures in petri dishes were incubated in a constant-flow humidified atmosphere of $3 \%$ $\mathrm{CO}_{2}$ in air. Growth medium was reinforced Eagle medium (REM) containing $2.2 \mathrm{mg}$ of $\mathrm{NaHCO}_{3}$ per $\mathrm{ml}$ and $10 \%$ heat-inactivated fetal calf serum. Fluid maintenance medium after virus infection was REM containing $1.5 \mathrm{mg}$ of $\mathrm{NaHCO}_{3}$ per $\mathrm{ml}$ and $0.2 \%$ bovine albumin (BA). The agar overlay medium was REM containing $50 \mu \mathrm{g}$ of diethylaminoethyl-dextran per ml, $1.5 \mathrm{mg}$ of $\mathrm{NaHCO}_{3}$ per ml, $0.2 \% \mathrm{BA}$, and $0.6 \%$ Ionagar 2 .

Virus. The WSN strain of influenza virus which had been serially propagated in MDBK cells was also provided by P. W. Choppin. The virus was first passed twice in MDBK cells in the fluid medium at $39.5 \mathrm{C}$ and then cloned by three successive isolations of plaques formed on MDBK cells incubated at 39.5 C. The resultant clone was designated as wild-type virus $\left(\mathrm{ts}^{+}\right)$. Stock virus of the wild-type WSN was prepared in MDBK cells incubated at $33 \mathrm{C}$.

Plaque assay. Infectivity was determined by plaque assay on MDBK cells grown in $60-\mathrm{mm}$ plastic petri dishes. The virus sample to be assayed was diluted in phosphate-buffered saline (PBS) (8) containing $0.2 \% \mathrm{BA}$, and $0.1 \mathrm{ml}$ was inoculated. After adsorption for $30 \mathrm{~min}$ at $37 \mathrm{C}$, cultures received $3 \mathrm{ml}$ of agar overlay medium and were placed in incubators adjusted to either $33 \mathrm{C}$ or $39.5 \mathrm{C}$ as minimum and maximum levels, respectively. Plaque counting was done after 3 days of incubation at $39.5 \mathrm{C}$ and 4 days of incubation at $33 \mathrm{C}$. Plaques were visible without neutral red staining of cells as distinct turbid areas against the transparent background of normal cells.

Mutagenesis. MDBK cells infected with the wildtype WSN virus at a multiplicity of infection (MOI) of about 0.1 plaque-forming units (PFU) per cell were incubated at $33 \mathrm{C}$ with the fluid maintenance medium, containing various concentrations of 5fluorouracil (5-FU), ranging from 25 to $100 \mu \mathrm{g} / \mathrm{ml}$ $(0.2$ to $0.8 \mathrm{~mm})$. One group did not receive $5-\mathrm{FU}$. At $40 \mathrm{hr}$, when cultures without 5-FU showed an extensive cytopathic effect (CPE), fluids were harvested from all groups and used for mutagenized virus stocks.

Isolation of ts mutants. Screening of mutagenized virus stocks for selecting provisional ts mutants was performed by the method described by Simpson and Hirst (25). The virus stocks were diluted appropriately to give less than 20 plaques per dish and were inoculated into series of MDBK cell cultures. They were overlaid with agar medium and incubated at $33 \mathrm{C}$ for 3 days. Plaques were counted, and their borders were precisely defined, after which the cultures were transferred to a $39.5 \mathrm{C}$ incubator. On the following day the plaques showing no increase in size were isolated as provisional ts mutants, suspended in PBS with $0.2 \% \mathrm{BA}$, and stored at $-80 \mathrm{C}$. Confirmation of their ts character and the second cloning were done by plaque assay on two groups of
MDBK cell cultures, one incubated at $33 \mathrm{C}$ and the other at $39.5 \mathrm{C}$. When infectivity measured at $39.5 \mathrm{C}$ was less than $10 \%$ of that measured at $33 \mathrm{C}$, a plaque formed at $33 \mathrm{C}$ was isolated for further passage. This procedure was repeated, and clones showing a ratio of plaquing efficiency at $39.5 \mathrm{C}$ to that at $33 \mathrm{C}$ (efficiency of plating [EOP] 39.5/33) of $-3 \log _{10}$ or less at the third passage were chosen for the preparation of ts mutant virus stocks, and a plaque formed at $33 \mathrm{C}$ was isolated. A group of MDBK cells was infected with the plaque suspension diluted up to $1: 5$ and was incubated at $33 \mathrm{C}$ in the fluid maintenance medium. When CPE became pronounced, culture fluids were harvested and stored at $-80 \mathrm{C}$. Stocks containing at least $10^{7} \mathrm{PFU} / \mathrm{ml}$ and showing EOP $39.5 / 33$ of $-3 \log _{10}$ or less were considered as ts mutants and were numbered sequentially. During this screening procedure, therefore, each mutant was cloned at least three times by plaque isolation. With some clones, two or more additional plaque purifications were necessary before obtaining virus stocks of satisfactory quality.

One-step growth experiment. One-step growth experiments were performed for the purpose of physiological characterization of mutants. Monolayer cultures grown in 30-ml plastic bottles were infected at an MOI ranging from 5 to $20 \mathrm{PFU} /$ cell. Adsorption was carried out at $37 \mathrm{C}$ for $30 \mathrm{~min}$, and cultures received prewarmed fluid maintenance medium. Cultures to be incubated at the permissive temperature $(33 \mathrm{C})$ received the medium prewarmed at $37 \mathrm{C}$, whereas the nonpermissive temperature $(39.5 \mathrm{C})$ group received the medium kept at $45 \mathrm{C}$. Bottles were tightly stoppered and placed either in an incubator at $33 \mathrm{C}$ or completely immersed in a water bath held at $39.5 \mathrm{C}$ by a Braun Thermomix thermostat control unit. At $3 \mathrm{hr}$, the medium was removed, and prewarmed anti-WSN rabbit serum diluted to 1:500 was added. The antiserum of this dilution reduced the background virus titer due to residual inoculum to less than $10^{4} \mathrm{PFU} / \mathrm{ml}$. Cultures were kept at the respective temperatures for $10 \mathrm{~min}$ and washed with prewarmed PBS with $0.2 \%$ BA three times. The prewarmed fresh medium $(2 \mathrm{ml})$ was added, and incubation at the respective temperatures was resumed. At 12 and $24 \mathrm{hr}$ postinfection, cultures were examined microscopically, and the approximate proportion of cells showing the CPE was recorded. Culture fluids containing scraped-off cells were harvested, subjected to three cycles of rapid freezing and thawing, and clarified by lowspeed centrifugation. These samples, representing total viral activity in the culture, were assayed for infectious virus, ribonucleoprotein (RNP) antigen, hemagglutinin (HA), and neuraminidase activity. Infectivity titration was done by plaque assay at 33 $\mathrm{C}$ as described above. HA titration was done at 4 $\mathrm{C}$ because some mutants showed an unstable hemagglutination pattern at room temperature.

RNP antigen was measured by complementfixation test against guinea pig antiserum to RNP antigen of influenza $A$ virus, prepared by the method of Lief et al. (18). The test was performed by the method of Lennette (16), and antigen titer was ex- 
pressed as the highest dilution of antigen associated with less than $50 \%$ hemolysis.

Neuraminidase assay was performed with a fetuin substrate as described (15) except that incubation of the reaction mixture at $37 \mathrm{C}$ was extended to overnight. One unit of neuraminidase was defined as the amount of enzyme required to liberate sufficient $N$-acetyl neuraminic acid to give an optical density reading of 0.1 at $549 \mathrm{~nm}$. Fourfold dilution series of a given sample were mixed with fetuin. The neuraminidase activity was calculated from the dilution giving rise to an optical density of less than 0.6 , where the optical density was a linear function of enzyme activity.

Mixed infection. Mixed infection for genetic analysis was performed in monolayer cultures in $30-\mathrm{ml}$ plastic bottles, as described above. Cultures infected singly with each of the parent viruses were always included. The MOI of a given mutant virus was the same for both single and mixed infection and was in the range of 2 to $9 \mathrm{PFU} /$ cell. Cultures in duplicate were infected with the same inoculum. One bottle was incubated at $39.5 \mathrm{C}$ and the other at $33 \mathrm{C}$. At $10 \mathrm{hr}$ after infection, unless otherwise stated, the virus was harvested as described above. Virus titration was done by plaque assay at 33 and at $39.5 \mathrm{C}$. Recombination frequency was calculated by the following formula (19):

$$
\frac{\left[A B_{33}\right]_{39.5}-\left(\left[A_{33}\right]_{39.5}+\left[B_{33}\right]_{39.5}\right)}{\left[A B_{33}\right]_{33}} \times 100
$$

where $\left[A B_{33}\right]_{33}$ and $\left[A B_{33}\right]_{39.5}$ are the titers of mixed yield grown at $33 \mathrm{C}$ but assayed at 33 and $39.5 \mathrm{C}$, respectively, and $\left[A_{33}\right]_{39.5}$ and $\left[B_{33}\right]_{39.5}$ are titers of single yields grown at $33 \mathrm{C}$ and assayed at $39.5 \mathrm{C}$. Efficiency of complementation was expressed by complementation levels calculated by a modification of the method used by Simpson and Hirst (25) in the following way:

$$
\frac{\left[A B_{39.5}\right]_{33}-\left(\left[A B_{39.5}\right]_{39.5}+\left[A_{39.5}\right]_{33}+\left[B_{39.5}\right]_{83}\right)}{\left[A_{39.5}\right]_{38}+\left[B_{39.5}\right]_{33}}
$$

$\left[A B_{39.5}\right]_{33}$ and $\left[A B_{39.5}\right]_{39.5}$ are the titers of mixed yield grown at 39.5 but assayed at 33 and $39.5 \mathrm{C}$, respectively. $\left[A_{39.5}\right]_{33}$ and $\left[B_{39.5}\right]_{33}$ are titers of single yields grown at $39.5 \mathrm{C}$ and assayed at $33 \mathrm{C}$.

\section{RESULTS}

Isolation of ts mutants. The permissive and nonpermissive temperatures employed in this study were 33 and $39.5 \mathrm{C}$, respectively. The EOP $39.5 / 33$ of wild-type WSN viruses was between 25 and $40 \%$. This was not due to the inhomogeneity of population with respect to growth capability at $39.5 \mathrm{C}$, because all plaques formed at $33 \mathrm{C}$ showed a significant increase in size after shifting of cultures to $39.5 \mathrm{C}$, and the incubation at $33 \mathrm{C}$ for the first $18 \mathrm{hr}$, during which no visible plaque appeared, and subsequent transfer to $39.5 \mathrm{C}$ resulted in EOP $39.5 / 33$ of
$100 \%$. The slightly lower EOP at $39.5 \mathrm{C}$ was probably a consequence of reduced viral stability at $39.5 \mathrm{C}$, particularly at the beginning of plaque development. With the wild-type WSN, plaque number reached a plateau in 2 days at $39.5 \mathrm{C}$ and in 3 days at $33 \mathrm{C}$. But because most ts mutants grew more slowly than the wild-type WSN even at the permissive temperature, final plaque counting was done after 3 days and 4 days of incubation at 39.5 and $33 \mathrm{C}$, respectively.

From 4,789 plaques of WSN virus mutagenized with 5-FU of concentrations between 25 and $100 \mu \mathrm{g} / \mathrm{ml}, 15$ mutants were obtained. The frequency of isolation of mutants from mutagenized virus stocks did not necessarily correlate with the concentration of 5-FU employed. There was no stable ts mutant among 1,370 plaques of untreated wild-type WSN. Table 1 shows the infectivity titer of 15 mutants assayed at permissive and nonpermissive temperatures. Only large and distinct plaques formed at $39.5 \mathrm{C}$, resembling those of wild-type virus, were counted. EOP 39.5/33 listed in Table 1, therefore, is thought to reflect the reversion frequency. At the nonpermissive temperature, in addition to the above plaques, some mutants produced extremely small and faint plaques that could hardly be counted. The number of these microplaques varied from experiment to experiment and were greatly influenced by minor changes in incubation temperature. The extent of appearance of these plaques correlated with the virus production at the nonpermissive temperature in one-

TABLE 1. PFU titer of ts mutants assayed at permissive and nonpermissive temperatures

\begin{tabular}{l|c|c|r}
\hline & \multicolumn{2}{|c|}{ PFU/ml assayed at: } & \multicolumn{1}{|c}{$\begin{array}{c}\text { EOP } 39.5 / 33^{a} \\
\left(-\log _{10}\right)\end{array}$} \\
\cline { 2 - 3 } & $33 \mathrm{C}$ & $39.5 \mathrm{C}$ & \\
\cline { 2 - 3 } ts-1 & $1.9 \times 10^{8}$ & $3.4 \times 10^{3}$ & 4.8 \\
ts-2 & $2.8 \times 10^{7}$ & $<10$ & $>6.4$ \\
ts-3 & $3.5 \times 10^{8}$ & $6.7 \times 10^{4 b}$ & 3.7 \\
ts-4 & $5.0 \times 10^{7}$ & $1.0 \times 10^{3}$ & 4.7 \\
ts-5 & $7.3 \times 10^{7}$ & $9.5 \times 10^{3}$ & 3.9 \\
ts-6 & $2.7 \times 10^{8}$ & $1.6 \times 10^{3}$ & 5.2 \\
ts-7 & $3.9 \times 10^{8}$ & $1.3 \times 10^{4 b}$ & 4.5 \\
ts-8 & $2.7 \times 10^{8}$ & $<10$ & $>6.4$ \\
ts-9 & $2.8 \times 10^{7}$ & $2.0 \times 10^{2}$ & 5.2 \\
ts-10 & $4.7 \times 10^{7}$ & $7.0 \times 10^{2}$ & 4.8 \\
ts-11 & $1.2 \times 10^{8}$ & $1.1 \times 10^{4 b}$ & 4.0 \\
ts-12 & $2.3 \times 10^{7}$ & $1.0 \times 10^{3}$ & 4.4 \\
ts-13 & $3.0 \times 10^{7}$ & $<10^{2}$ & $>5.5$ \\
ts-14 & $5.7 \times 10^{7}$ & $<10^{2}$ & $>5.8$ \\
ts-15 & $1.7 \times 10^{8}$ & $2.3 \times 10^{3}$ & 4.9 \\
\hline
\end{tabular}

a See Materials and Methods for definition.

$b$ In addition to the value listed, there were "leak" plaques. 
step growth to be discussed below. Since the majority of virus produced at the nonpermissive temperature still retained ts character, the virus production was due to the leakiness of the particular mutant. Therefore, those microplaques produced at the nonpermissive temperature were probably also due to the leakiness.

PFU titration was less accurate at $39.5 \mathrm{C}$ than at $33 \mathrm{C}$, because of demonstrated topographical temperature differences within the incubator and minor temperature fluctuations. In repeated titration of the same virus sample at $39.5 \mathrm{C}$, a fluctuation of PFU titer over a two- to threefold range was not uncommon.

Growth of ts $^{+}$virus and ts mutants. Figure 1 shows one-step growth curves of wild-type WSN, ts-3, and ts- 8 at permissive and nonpermissive temperatures. Growth of wild-type virus proceeds 1 to $2 \mathrm{hr}$ earlier at $39.5 \mathrm{C}$ than at $33 \mathrm{C}$. There was no recognizable increase in infectious virus of ts-8, whereas ts-3 showed a small but definite increase in infectious virus at the nonpermissive temperature, indicating that ts-3 is either leaky or moderately reverting, or both.

Viral functions at permissive and nonpermissive temperatures. To find temperature-dependent defects in physiological functions, development of CPE and production of RNP antigen, hemagglutinin, neuraminidase, and infectious virus were examined during one-step growth at permissive and nonpermissive temperatures. Figure 2 shows the extent of CPE and yield of viral products at $12 \mathrm{hr}$ after infection. The pattern 24 $\mathrm{hr}$ after infection was essentially the same except for a few minor changes. With mutants other than ts-7, the yield of infectious virus at $39.5 \mathrm{C}$ was less than $0.1 \%$ of that at $33 \mathrm{C}$. ts- 7 was leaky (Table 1 ), and the difference was only 100 -fold. Expression of other viral functions differed greatly from one mutant to the other. Whereas with

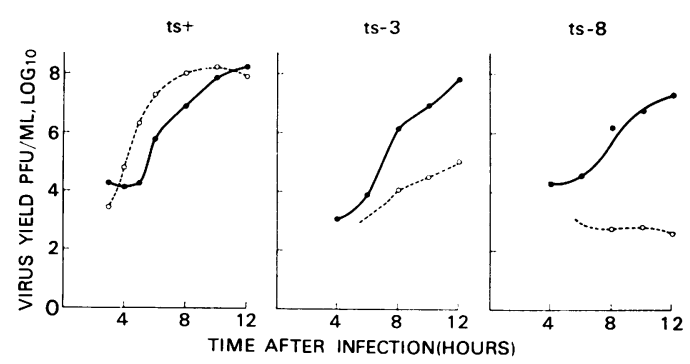

FIG. 1. One-step growth curve of $t s^{+}, t s-3$, and $t s-8$ at $33 C(\bigcirc)$ and $39.5 C(O)$. One-step growth experiments were done by the method described in Materials and Methods. At indicated times, both culture fluid and cells were harvested. PFU titration was done at $33 \mathrm{C}$. some mutants (for example, ts- 3 , ts- 6 , ts- 9 , ts- 11 , ts-13, and ts-14), it was evident which step(s) was prevented from expression under the nonpermissive condition, some mutants (e.g., ts-1, ts-4, ts-5, and ts-10) exhibited subnormal expression of function(s) at $39.5 \mathrm{C}$, thus making it difficult to decide whether or not the particular function is truly defective. However, if it is arbitrarily decided that the reduction of a functional value obtained at $33 \mathrm{C}$ by less than $75 \%$ at $39.5 \mathrm{C}$ signifies preservation of normal genetic function, then the results presented in Fig. 2 can be simplified as illustrated in Table 2. Mutants were classified in five groups. Those belonging to group A failed to manifest any activity when examined at $39.5 \mathrm{C}$. Group E mutants exhibited all activities except for the production of infectious virus. Mutants of groups B, C, and D were intermediate. Included in Fig. 2 are data on the behavior of two stocks ( $a$ and $b$ ) of ts-2, derived from different clones of the same parent. Stock a has been listed as group B in Table 2, whereas stock b might be assigned to group $D$. This dissimilarity in physiological characterization of ostensibly genetically identical virus clones is difficult to explain. Factors other than genotype might also influence the expression of gene functions.

Mixed infection. Representative results of mixed infection leading to highly efficient recombination and complementation are presented in Table 3. Recombination frequency and complementation level were computed according to formulae described in Materials and Methods. Table 4 presents the typical example of a cross which showed no sign of recombination or complementation. It was concluded from these results that ts- 1 and ts- 6 have a mutation in the same portion of the genome, or belong to the same recombination (or complementation) group. In more than 80 crosses conducted, recombination either occurred with a frequency in excess of $0.4 \%$ or was undetectable at the level of $0.01 \%$. No intermediate frequency was encountered. Similarly, the complementation level was either in a range from 21 to 17,900 or less than 2.

Effect of multiplicity of infection on recombination. Table 5 shows the recombination frequencies in crosses between ts- 3 and ts- 8 inoculated at MOI values differing over a 10- to 100fold range. Recombination frequencies obtained with low MOI values were significantly higher than expected from the calculated proportion of mixedly infected cells, suggesting that both mutant stocks contained a large number of virus particles, noninfectious per se, yet capable of participating in genetic interaction. An addi- 


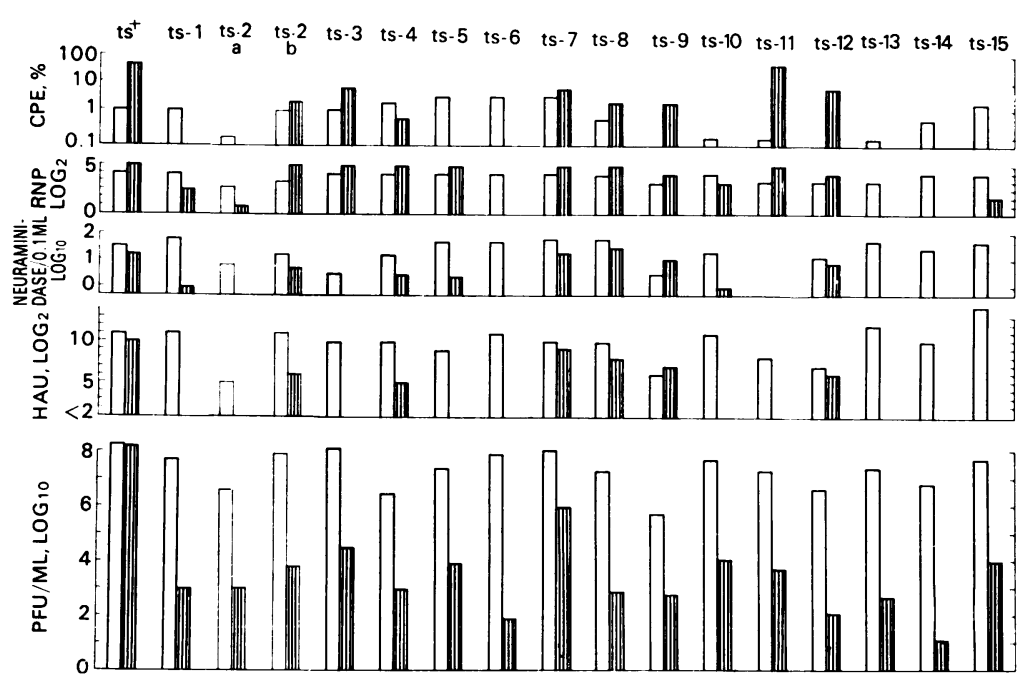

Fig. 2. CPE, RNP antigen, neuraminidase, $H A$, and infectious virus produced by $t^{+}$and ts mutants at $33 C$ (open columns) and $39.5 C$ (shaded columns). One-step growth experiment was performed by the method described in Materials and Methods. MOI was between 5 and $20 \mathrm{PFU} /$ cell. At $12 \mathrm{hr}, \mathrm{CPE}$ was scored microscopically. Both culture fluid and cells were harvested and titrated for RNP antigen, neuraminidase activity, $H A$, and PFU.

TABLE 2. Summary of physiological characterization of ts mutants ${ }^{a}$

\begin{tabular}{|c|c|c|c|c|c|c|}
\hline Group & $\begin{array}{c}\text { RNP } \\
\text { antigen }\end{array}$ & $\mathrm{CPE}$ & $\begin{array}{c}\text { Neuramin- } \\
\text { idase }\end{array}$ & HA & PFU & Clones \\
\hline A & - & - & - & - & - & ts -6, ts -13, ts -14, ts -15 \\
\hline B & + & - & - & - & - & ts -1, ts $-2 a$, ts -4, ts -5, ts -10 \\
\hline $\mathrm{C}$ & + & + & - & - & - & ts -3, ts -11 \\
\hline D & + & + & + & - & - & ts $-2 b$ \\
\hline $\mathrm{E}$ & + & + & + & + & - & ts -7, ts -8, ts -9, ts -12 \\
\hline Wild-type & + & + & + & + & + & $\mathrm{ts}^{+}$ \\
\hline
\end{tabular}

${ }^{a}+$, Yield or function at $39.5 \mathrm{C}$ is $25 \%$ or more of yield or function at $33 \mathrm{C}$; - , yield or function at $39.5 \mathrm{C}$ is less than $25 \%$ of yield or function at $33 \mathrm{C}$.

TABLE 3. Virus yield after single and mixed infections with $t s-3$ and $t s-8^{a}$

\begin{tabular}{|c|c|c|c|c|}
\hline \multicolumn{2}{|c|}{$\begin{array}{l}\text { Input MOI } \\
\text { (PFU/cell) }\end{array}$} & \multirow{2}{*}{$\begin{array}{c}\text { Incubation } \\
\text { temp (C) }\end{array}$} & \multicolumn{2}{|c|}{$\begin{array}{c}10-\mathrm{hr} \text { yield }(\mathrm{PFU} / \mathrm{ml}) \\
\text { assayed at }\end{array}$} \\
\hline ts-3 & ts -8 & & $33 \mathrm{C}$ & $39.5 \mathrm{C}$ \\
\hline 8.8 & 0 & $\begin{array}{l}33 \\
39.5\end{array}$ & $\begin{array}{l}9.2 \times 10^{6} \\
3.4 \times 10^{4}\end{array}$ & $7.8 \underset{20}{\times} 10^{3}$ \\
\hline 0 & 6.7 & $\begin{array}{l}33 \\
39.5\end{array}$ & $\begin{array}{l}5.3 \times 10^{6} \\
7.2 \times 10^{2}\end{array}$ & $\begin{array}{l}<3 \\
<3\end{array}$ \\
\hline 8.8 & 6.7 & $\begin{array}{l}33 \\
39.5\end{array}$ & $\begin{array}{l}2.3 \times 10^{7} \\
1.8 \times 10^{7}\end{array}$ & $\begin{array}{l}1.6 \times 10^{6} \\
5.0 \times 10^{5}\end{array}$ \\
\hline
\end{tabular}

${ }^{a}$ Recombination frequency:

$$
\frac{1.6 \times 10^{6}-\left(7.8 \times 10^{3}+0\right)}{2.3 \times 10^{7}} \times 100=7.0 \% \text {. }
$$

Complementation level:

$\frac{1.8 \times 10^{7}-\left(5.0 \times 10^{5}+3.4 \times 10^{4}+7.2 \times 10^{2}\right.}{3.4 \times 10^{4}+7.2 \times 10^{2}}$
TABLE 4. Virus yield after single and mixed infections with $t s-1$ and $t s-6^{a}$

\begin{tabular}{|c|c|c|c|c|}
\hline \multicolumn{2}{|c|}{$\begin{array}{l}\text { Input MOI } \\
\text { (PFU/cell) }\end{array}$} & \multirow{2}{*}{$\begin{array}{l}\text { Incubation } \\
\text { temp }\end{array}$} & \multicolumn{2}{|c|}{$\begin{array}{c}\text { 10-hr yield }(\mathrm{PFU} / \mathrm{ml}) \\
\text { assayed at }\end{array}$} \\
\hline ts-1 & ts-6 & & $33 \mathrm{C}$ & $39.5 \mathrm{C}$ \\
\hline 4.8 & 0 & $\begin{array}{l}33 \mathrm{C} \\
39.5 \mathrm{C}\end{array}$ & $\begin{array}{l}1.1 \times 10^{7} \\
9.0 \times 10^{2}\end{array}$ & $2.0 \underset{27}{\times} 10^{2}$ \\
\hline 0 & 6.7 & $\begin{array}{l}33 \mathrm{C} \\
39.5 \mathrm{C}\end{array}$ & $\begin{array}{l}2.5 \times 10^{7} \\
2.1 \times 10^{2}\end{array}$ & $1.1 \underset{13}{\times} 10^{2}$ \\
\hline 4.8 & 6.7 & $\begin{array}{l}33 \mathrm{C} \\
39.5 \mathrm{C}\end{array}$ & $\begin{array}{l}2.8 \times 10^{7} \\
1.5 \times 10^{3}\end{array}$ & $1.2 \underset{27}{\times} 10^{2}$ \\
\hline
\end{tabular}

a Recombination frequency:

$$
\begin{aligned}
& \frac{1.2 \times 10^{2}-\left(2.0 \times 10^{2}+1.1 \times 10^{2}\right)}{2.8 \times 10^{7}} \\
& \times 100=<3.6 \times 10^{-60} \%
\end{aligned}
$$

Complementation level:

$\frac{1.5 \times 10^{3}-\left(2.7 \times 10^{1}+9.0 \times 10^{2}+2.1 \times 10^{2}\right)}{9.0 \times 10^{2}+2.1 \times 10^{2}}$

$=0.3$. 
TABLe 5. Effect of differing multiplicities of infection on genetic recombination and complementation $^{a}$

Recombination frequency $(\%)$

\begin{tabular}{l|l|r|r|r}
\hline & \multicolumn{2}{|c}{ ts-3 MOI (PFU/cell) } \\
\cline { 3 - 4 } & & 8.8 & 0.88 & 0.088 \\
\hline $\begin{array}{l}\text { ts-8 MOI (PFU/ } \\
\text { cell) }\end{array}$ & 6.7 & 11.7 & 3.6 & $\mathrm{NT}$ \\
& 0.67 & 9.1 & 6.9 & $\mathrm{NT}$ \\
& 0.067 & 1.9 & 5.3 & 5.3 \\
\hline
\end{tabular}

Complementation level

\begin{tabular}{l|l|r|r|r}
\hline & \multicolumn{2}{|c}{ ts-3 MOI (PFU/cell) } \\
\cline { 3 - 4 } & 8.8 & 0.88 & 0.088 \\
\hline $\begin{array}{l}\text { ts-8 MOI (PFU/ } \\
\text { cell) }\end{array}$ & 6.7 & 800 & 270 & $\mathrm{NT}$ \\
& $\begin{array}{l}0.67 \\
0.067\end{array}$ & $\begin{array}{r}\text { N08 } \\
64\end{array}$ & $\begin{array}{r}1,000 \\
520\end{array}$ & $\begin{array}{c}\mathrm{NT} \\
410\end{array}$ \\
\hline
\end{tabular}

a Cultures were either singly or mixedly infected at different MOI values. Progeny virus was harvested at $10 \mathrm{hr}$. NT, Not tested.

tional reason might be that because virus replication proceeds faster in cells infected with two or more virions than in those infected with a single virion, the yield from mixedly infected cells is overrepresented at $10 \mathrm{hr}$ after infection, the time at which infectious virus is still increasing.

Kinetics of recombination. Virus was harvested at different time intervals after mixed infection and examined for recombination frequency. The proportion of ts $^{+}$recombinants in mixed yields increased steadily from 1 to $19 \%$ over the period of 5 to $12 \mathrm{hr}$, during which the total infectious virus multiplied more than 2,000fold (Fig. 3).

Classification of mutants. An attempt has been made to assign mutants to recombination groups by pairwise crosses, conducted in the same manner as illustrated in Tables 3 and 4 . The recombination frequency between $10 \mathrm{mu}$ tants is shown in Table 6. Nine mutants were unambiguously classified into five recombination groups. Within a group, recombination was undetectable at the level of $0.01 \%$, but between viruses of different groups the recombination frequency at $10 \mathrm{hr}$ ranged from 0.43 to $16.8 \%$. ts-13 did not recombine with mutants belonging to either of two different groups (groups I and III) and was thus thought to be a double mutant. Five mutants which are not included in Table
6 have been assigned similarly to recombination groups. Classification of all 15 mutants is summarized in Table 7.

In these experiments, the presence or absence of complementation was also determined, but there was no discrepancy between complementation and recombination, i.e., any two mutants which recombined were found to complement each other (complementation level ranging from 21 to 17,900), and no two mutants which did not recombine proved to be complementary in genetic function.

\section{DISCUSSION}

A significant finding of this study is that recombination is either very efficient (with the frequency exceeding $0.4 \%$ ) or undetectable at the level of $0.01 \%$. The most plausible explanation for this "all or none" pattern of recombination is that (i) the genome of influenza virus consists of a number of physically discrete units or "subgenomic pieces" (12) within which the exchange of genetic materials does not occur, and (ii) genetic recombination in influenza virus represents exchange of these physically discrete units. Simpson and Hirst (25), in their study of ts mutants of WSN influenza virus, made essentially the same observation. Crossing of different ts mutants resulted either in the emergence of "wild-type" recombinants at a frequency of 5 to $20 \%$ of the total progeny virus or recombinant yields too low to be detectable. A similar pattern,

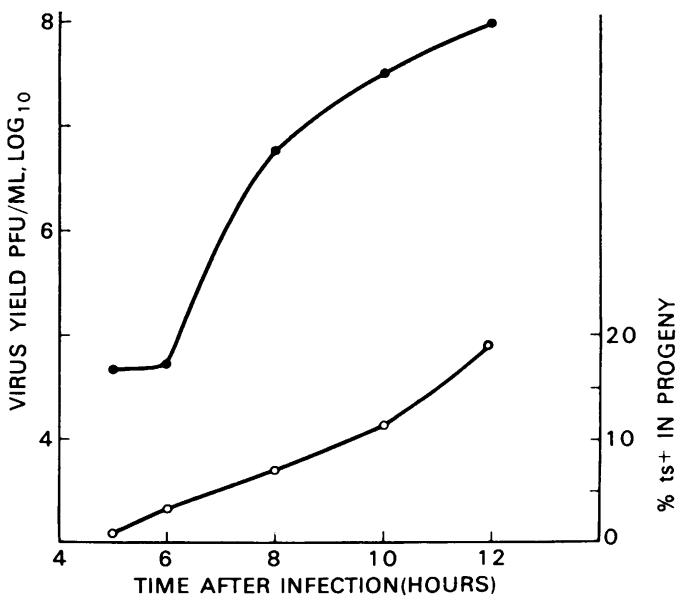

FIG. 3. Kinetics of recombination. Cultures were mixedly infected with $t s-3$ and $t s-8$ at MOI values of 8.8 and $6.7 \mathrm{PFU} /$ cell, respectively. Progeny virus was harvested at indicated times. Symbols: (O) virus yield, i.e., the titer of mixed yield assayed at $33 \mathrm{C}$; (O) percentage of $\mathrm{ts}^{+}$(assayed at $39.5 \mathrm{C}$ ) in the mixed yield. 
TABLE 6. Recombination frequency in pairwise crosses between ts mutants

\begin{tabular}{|c|c|c|c|c|c|c|c|c|c|c|}
\hline \multirow{3}{*}{ Mutants } & \multicolumn{10}{|c|}{ Recombination frequency $(\%)^{a}$} \\
\hline & \multicolumn{2}{|c|}{$\mathrm{I}^{b}$} & \multicolumn{2}{|c|}{ II } & \multicolumn{2}{|c|}{ III } & \multicolumn{2}{|c|}{ IV } & \multirow{2}{*}{$\frac{\mathrm{V}}{\mathrm{ts}-12}$} & \multirow{2}{*}{$\frac{I \& I I I}{\text { ts-13 }}$} \\
\hline & ts-1 & ts -8 & ts-7 & ts -10 & ts -5 & ts -15 & ts-3 & ts-11 & & \\
\hline $\begin{array}{l}\text { ts-1 } \\
\text { ts-8 }\end{array}$ & - & $\underline{0}$ & $\begin{array}{l}0.56 \\
3.0\end{array}$ & $\begin{array}{l}1.2-2.5 \\
6.1\end{array}$ & $\begin{array}{l}4.5-6.5 \\
6.1-16.8\end{array}$ & $\begin{array}{l}1.4-2.7 \\
0.54-4.7\end{array}$ & $\begin{array}{l}8.5 \\
7.0-11.7\end{array}$ & $\begin{array}{l}2.0 \\
3.2\end{array}$ & $\begin{array}{c}\mathrm{NT}^{c} \\
3.7-12.0\end{array}$ & $\begin{array}{l}0 \\
0\end{array}$ \\
\hline $\begin{array}{l}\text { ts }-7 \\
\text { ts-10 }\end{array}$ & & & - & ${ }^{0}$ & $\begin{array}{l}1.0 \\
0.8-5.6\end{array}$ & $\begin{array}{l}5.9 \\
2.5-4.3\end{array}$ & $\begin{array}{l}3.5 \\
6.3\end{array}$ & $\begin{array}{l}1.6 \\
0.9-2.5\end{array}$ & $\begin{array}{l}2.5 \\
\mathrm{NT}\end{array}$ & $\begin{array}{l}5.7 \\
1.0\end{array}$ \\
\hline $\begin{array}{l}\text { ts }-5 \\
\text { ts }-15\end{array}$ & & & & & - & ${ }^{0}$ & $\begin{array}{r}10.0 \\
3.2\end{array}$ & $\begin{array}{l}8.2 \\
0.61-1.3\end{array}$ & $3.0^{\mathrm{NT}}$ & $\begin{array}{l}0 \\
0\end{array}$ \\
\hline $\begin{array}{l}\text { ts-3 } \\
\text { ts-11 }\end{array}$ & & & & & & & - & ${ }^{0}$ & $\begin{array}{l}\mathrm{NT} \\
0.43\end{array}$ & $\begin{array}{l}2.7 \\
1.6\end{array}$ \\
\hline ts -12 & & & & & & & & & - & 1.1 \\
\hline ts -13 & & & & & & & & & & - \\
\hline
\end{tabular}

a With crosses conducted more than once, the range of recombination frequency is shown. $0=$ Less than $0.01 \%$.

${ }^{b}$ Group number.

c NT, Not tested.

TABLE 7. Classification of ts mutants into recombination groups

\begin{tabular}{|c|c|c|}
\hline $\begin{array}{l}\text { Recombina- } \\
\text { tion groups }\end{array}$ & Single mutants & Double mutants \\
\hline$\underset{\text { II }}{\text { II }}$ & $\begin{array}{l}\text { ts }-1, \text { ts }-6, \text { ts }-8 \\
\text { ts }-4, \text { ts }-7, \text { ts }-10 \\
\text { ts }-5, \text { ts }-9, \text { ts }-15 \\
\text { ts }-3, \text { ts }-11 \\
\text { ts }-12\end{array}$ & $\begin{array}{l}\text { ts }-13, \text { ts }-14 \\
\text { ts }-2, \text { ts }-14 \\
\text { ts }-2, \text { ts }-13\end{array}$ \\
\hline
\end{tabular}

although less pronounced, has been observed in recombination between ts mutants of vesicular stomatitis virus. The recombination frequency was either in the range from 0.29 to $2.31 \%$ or less than $0.02 \%$ (23). Reovirus behaved in a similar manner; recombination occurred with a frequency of 3 to $50 \%$ or zero (11). Unlike Mackenzie (19), we could not find evidence of additivity in recombination frequency. The recombination frequency did actually vary over a 30 -fold range from one pairwise cross to the other. The differences, however, were not self-consistent among mutants of different recombination groups, and therefore it was not possible to construct a scheme by which different frequencies were arranged in a linear or circular sequence. In this regard, data presented in Table 6 strikingly resemble those found in recombination experiments with reo- virus, which have been interpreted in favor of random assortment of genome fragments (10). Fluctuation of recombination frequency in repeated tests of the same cross (Table 6) makes it difficult to assess the significance of the observed difference, although we have not analyzed it statistically. One of the reasons for the observed difference or fluctuation in recombination frequency was probably the relative inaccuracy of PFU assay at $39.5 \mathrm{C}$ compared with that at $33 \mathrm{C}$ in our system. Furthermore, the recombination frequency varied depending upon such factors as the relative proportion of two infecting parents and the chronology of the replicative process. Therefore, it was difficult to reproduce identical experimental conditions for all pairwise crosses of mutants. Under these circumstances, demonstration of additivity of recombination frequency, if it did exist, would have been very difficult.

Complementation between mutants of different groups was generally very efficient in this study, a complementation level as high as 17,900 being reached in some crosses. It is possible, however, as has been suspected (25), that complementation is greatly facilitated by the early appearance of the recombinant genome. Simpson and Hirst (25) described complementation unaccompanied by recombination, which might be interpreted as either intragenic complementa- 
tion or the existence of a subgenomic fragment comprising two or more genes. We have not so far encountered such disparity.

There were six mutants showing EOP 39.5/33 less than $-5 \log _{10}$. Four of them (ts-6, ts-8, ts-13, and ts-14) were classified as group $A$ in physiological characterization (Table 2), that is, they did not manifest any gene expression examined. They all showed minimal degree of leakiness (Fig. 2) and were initially thought to be mutants most suitable for further characterization. Of these four "good" mutants, however, at least two (ts-13 and ts-14) were found to be double mutants. Presumably when stringent criteria are used for selection of ts mutants, a substantial proportion of them are likely to be double mutants. The above finding also validates the suggestion that any ts ribovirus mutant that fails to show significant revertant or "leak" plaques under the restrictive condition is almost certain to be a double mutant (3).

Difficulties in correlating physiological defects with mutation loci upon the genome appeared twofold. First, the pattern of gene expression in physiological characterizaion does not always agree with the results of genetic characterization. ts-1, ts-6, ts-13, and ts-14, having mutation at gene I, exhibited more or less similar physiology at the nonpermissive temperature. Group IV mutants, ts-3 and ts-11, also were similar in physiological defects not only at the nonpermissive temperature, but they shared a reduced production of neuraminidase relative to hemagglutinin at the permissive temperature. They were both very leaky (Table 1 ). On the other hand, ts- 1 and ts- 6 versus ts- 8 in group I, ts-4, ts-7, and ts-10 in group II, and ts-5, ts-9, and ts-15 in group III behaved differently in gene expression at the nonpermissive temperature. Conversely, some mutants of different groups showed similar manifestations in physiological tests (e.g., ts-7, ts-8, ts-9, and ts-12). Discrepancy in physiology within a reombination group is also exemplified by the behavior of two stocks of the same mutant, ts-2a and ts-2b (Fig. 2). It is suggested, therefore, that the functional expression of the genome is dependent not only upon the location of mutation on the genome but also on some other factors such as leakiness of the genetic defect, reversion frequency, and revertant content of the virus stock employed. Secondly, the existence of asymmetric covariation (3) of gene function is suggested by results of physiological characterization (Table 2). It appears to take the following order: RNP antigen synthesis, development of CPE, and production of functional neuraminidase and HA, each step seemingly constituting a prerequisite for the occurrence of the subsequent events. Of course, the existence of asymmetric covariation cannot be definitely proven, unless sufficiently large numbers of mutants are examined. If this is the case, however, the sequence of events would have to be definitely established before any attempt to correlate genetic and functional defects is made.

An interesting and positive contribution from the physiological characterization studies is the suggestion that CPE is not the necessary and direct result of virus infection per se, but rather its appearance is dependent upon the active participation of gene product(s), presumably those other than RNP antigen alone.

The present study has confirmed our previous finding that recombination frequency increases during viral replication (28). The resemblance to recombination in bacteriophage, however, may not necessarily imply a similarity of underlying mechanism, i.e., multiple rounds of mating during replication of the viral genome (30). Rather, rapid encapsidation of viral RNA after its synthesis $(6,26)$ and the emergence of recombinants as early as $5 \mathrm{hr}$ (Fig. 3) suggest the contrary. Chronological increase in the recombinant proportion could be due to the gradual expansion and overlapping of two or more replicating matrices and, therefore, could be dependent upon virus-cell systems and experimental conditions employed. In fact, one of us (K. T.) has observed that the proportion of recombinants remained unchanged after mixed infection in a different system (Arch. Gesamte Virusforsch., in press).

\section{ACKNOWLEDG MENTS}

This investigation was conducted under the auspices of the Commission on Influenza, Armed Forces Epidemiological Board. It was supported by the U.S. Army Medical Research and Development Command, Department of the Army, under research contract DA-49-183-MD-2795, by Public Health Service research grant AI-01595 from the National Institute of Allergy and Infectious Diseases, and also by the Health Research Council of the City of New York under contract U-1023.

We thank Jan A. Meisels for her technical assistance.

\section{LITERATURE CITED}

1. Choppin, P. W. 1969. Replication of influenza virus in a continuous cell line: high yield of infective virus from cells inoculated at high multiplicity. Virology 39:130-134.

2. Content, J., and P. H. Duesberg. 1971. Base sequence difference among the ribonucleic acids of influenza virus. J. Mol. Biol. 62:273-285.

3. Cooper, P. D. 1969. The genetic analysis of poliovirus, p. 177218. In H. B. Levy (ed.), The biochemistry of viruses. Marcell Dekker, New York.

4. Davies, P., and R. D. Barry. 1966. Nucleic acid of influenza virus. Nature (London) 211:384-387.

5. Duesberg, P. H. 1968. The RNA's of influenza virus. Proc. Nat. Acad. Sci. U.S.A. 59:930-937. 
6. Duesberg, P. H. 1969. Distinct subunits of the ribonucleoprotein of influenza virus. J. Mol. Biol. 42:485-499.

7. Duesberg, P. H., and W. S. Robinson. 1967. On the structure and replication of influenza virus. J. Mol. Biol. 25:383-405.

8. Dulbecco, R., and M. Vogt. 1954. Plaque formation and isolation of pure lines with poliomyelitis virus. J. Exp. Med. 99:167-182.

9. Fenner, F., and J. F. Sambrook. 1964. The genetics of animal viruses. Annu. Rev. Microbiol. 18:47-94.

10. Fields, B. N. 1971. Temperature-sensitive mutants of reovirus type 3. Features of genetic recombination. Virology 46:142148.

11. Fields, B. N., and W. K. Jokiik. 1969. Isolation and preliminary genetic and biochemical characterization of temperature-sensitive mutants of reovirus. Virology 37:335-342.

12. Hirst, G. K. 1962 . Genetic recombination with Newcastle disease virus, polioviruses, and influenza. Cold Spring Harbor Symp. Quant. Biol. 27:303-309.

13. Kilbourne, E. D. 1963. Influenza virus genetics. Progr. Med. Virol. 5:79-126.

14. Kingsbury, D. W., and R. G. Webster. 1969. Some properties of influenza virus nucleocapsid. J. Virol. 4:219-225.

15. Laver, W. G., and E. D. Kilbourne. 1966. Identification in a recombinant influenza virus of structural proteins derived from both parents. Virology 30:493-501

16. Lennette, E. H. 1964. General principles underlying laboratory diagnosis of viral and rickettsial intections, p. 1-66. In E. H. Lennette and N. J. Schmidt (ed.), Diagnostic procedures for viral and rickettsial diseases, 3rd ed. American Public Health Association, New York.

17. Lewandowski, L. J., J. Content, and S. H. Leppla. 1971. Characterization of the subunit structure of the ribonucleic acid genome of influenza virus. J. Virol. 8:701-707.

18. Lief, F. S., A. Fabiyi, and W. Henle. 1958. Antigenic analysis by complement fixation. I. The production of antibodies to the soluble antigen in guinea pigs. J. Immunol. 80:53-65.
19. Mackenzie, J. S. 1970. Isolation of temperature-sensitive mutants and the construction of a preliminary genetic map for influenza virus. J. Gen. Virol. 6:63-75.

20. Nayak, N. P., and M. A. Baluda. 1967. Isolation and partial characterization of the nucleic acid of influenza virus. $J$. Virol. 1:1217-1223.

21. Pons, M. 1967. Studies on influenza virus ribonucleic acid. Virology 31:523-531.

22. Pons, M., and G. K. Hirst. 1968. Polyacrylamide gel electrophoresis of influenza virus RNA. Virology 34:385-388.

23. Pringle, C. R. 1970. The induction and genetic characterization of conditional lethal mutants of vesicular stomatitis virus, p. 567-582. In R. D. Barry and B. W. J. Mahy (ed.), The biology of large RNA viruses. Academic Press Inc., London.

24. Simpson, R. W. 1964. Genetic studies with influenza A virus, p. 187-206. In G. E. W. Wolstenholme and J. Knight (ed.), Ciba Foundation symposium on cellular biology of myxovirus infections. J. \& A. Churchill Ltd., London.

25. Simpson, R. W., and G. K. Hirst. 1968. Temperature-sensitive mutants of influenza $A$ virus: isolation of mutants and preliminary observations on genetic recombination and complementation. Virology 35:41-49.

26. Sugiura, A. 1972. Influenza viral RNA and ribonucleoprotein synthesized in abortive infection. Virology 47:51 7-520.

27. Sugiura, A., and E. D. Kilbourne. 1965. Genetic studies of influenza viruses. II. Plaque formation by influenza viruses in a clone of a variant human heteroploid cell line. Virology 26:478-488.

28. Sugiura, A., and E. D. Kilbourne. 1966. Genetic studies of influenza viruses. III. Production of plaque-type recombinants with $A_{0}$ and $A_{1}$ strains. Virology 29:84-91.

29. Tobita, K. 1971. Genetic recombination between influenza viruses $\mathbf{A}_{0} / \mathrm{NWS}$ and A2/Hong Kong. Arch. Gesamte Virusforsch. 34:119-130.

30. Visconti, N., and M. Delbriuck. 1953. The mechanism of genetic recombination in phage. Genetics 38:5-33. 